\title{
AKTIVITAS ANTIOKSIDAN EKSTRAK ETANOL DAUN KELADI TIKUS \\ (Typhonium flagelliforme) DENGAN METODE DPPH (1,1-Diphenyl-2-Picryhidrazyl)
}

\author{
ANTIOXIDANT ACTIVITY OF LEAF EXTRACT ETHANOL RODENT TUBER \\ (Typhonium flagelliforme) USING DPPH (1,1- Diphenyl-2-Picryhidrazyl)
}

\author{
KETUT AGUS ADRIANTA ${ }^{1 \bullet}$, NI NYOMAN WAHYU UDAYANI $^{1}$, HERLEEYANA MERIYANI $^{1}$ \\ ${ }^{1}$ Akademi Farmasi Saraswati Denpasar, Jalan Kamboja no. 11 A, Denpasar, Bali.
}

\begin{abstract}
Abstrak: Keladi tikus (Typhonium flagelliforme) suku Araceae merupakan salah satu tanaman obat Indonesia, yang diduga berkhasiat membunuh atau menghambat pertumbuhan sel kanker, menekan efek negatif dari proses pengobatan modern (khemoterapi) seperti rambut rontok, nafsu makan hilang, rasa mual dan rasa nyeri di tubuh, bersifat antivirus dan anti bakteri. Untuk itu perlu dilakukan penelitian dengan menguji aktivitas antioksidan ekstrak etanol daun keladi tikus yang terdapat di Sidakarya, Denpasar, Bali. Pengujian aktivitas antioksidan dilakukan terhadap ekstrak etanol daun keladi tikus dilakukan dengan metode penangkapan radikal DPPH. Pengujian ini diawali dengan penyiapan sampel, kemudian diekstraksi dengan metode ultrasonik dengan pelarut etanol. Uji aktivitas antioksidan diukur dengan spektrofotometer UV-Vis. Hasil persentase peredaman diplotkan untuk mendapat kurva regresi linier. Sehingga didapat persamaan $\mathrm{y}=\mathrm{bx}+\mathrm{a}$ dan nilai $\mathrm{IC}_{50}$ dihitung dari persamaan regresi linier yang diperoleh. Uji aktivitas antioksidan etanol daun keladi tikus diukur pada panjang gelombang $518 \mathrm{~nm}$. Dari kurva regresi diperoleh persamaan regresi adalah y $=0.527 \mathrm{x}+$ 9.891 dan $\mathrm{R}^{2}=0,985$. Nilai $\mathrm{IC}_{50}$ yang diperoleh sebesar $76.10 \mathrm{ppm}$. Antioksidan yang terkandung dalam ekstrak etanol daun keladi tikus dikatagorikan dalam antioksidan kuat.
\end{abstract}

Kata Kunci: antioksidan, DPPH, keladi tikus, spektrofotometri UV-Vis.

\begin{abstract}
Rodent Tuber (Typhonium flagelliforme) the Araceae is one of the medicinal plants in Indonesia, which is believed to be efficacious to kill or inhibit the growth of cancer cells, reducing the negative effects of the process of modern medicine (chemotherapy) such as hair loss, appetite loss, nausea and pain in the body, are antivirus and bacteria. For that research needs to test the antioxidant activity extracts ethanol leaves ringleader of mice that contained in Sidakarya, Denpasar, Bali. Testing antioxidant activity to extract ethanol leaves ringleader rats carried out by the method the arrest of radical DPPH. The test begins with the preparation of samples, then extracted by methods of ultrasonic maceration with solvent ethanol. The antioxidant activity measured by spectrophotometry. UV-Vis. The percentage reduction results were plotted to obtain a linear regression curve. And so are the equation $\mathrm{y}=\mathrm{bx}$ and value $\mathrm{IC}_{50}$ is calculated from the equation the regression linear obtained. The antioxidant activity ethanol leaves ringleader of a rat of $518 \mathrm{~nm}$. From the regression is $\mathrm{y}=0.527 \mathrm{x}+9.891$ and $\mathrm{R}^{2}=0,985$. The $\mathrm{IC}_{50}$ obtained by 76.10 parts per million (ppm). Antioxidants contained in the ethanol extract of taro leaves rats categorized in powerful antioxidants
\end{abstract}

Keywords: antioxidant, DPPH, Rodent tuber (Typhonium flagelliforme), UV-Vis spectrophotometry.

\section{PENDAHULUAN}

Di Indonesia, kesehatan merupakan masalah yang cukup serius. Faktor lingkungan seperti polusi, intensitas sinar Ultra violet (UV) yang berlebih, suhu, bahan kimia, dan kekurangan gizi dapat mengakibatkan tubuh manusia terpapar radikal bebas. Banyak penyakit yang disebabkan oleh radikal bebas, salah satunya adalah kanker. salah satu mekanisme untuk mengatasi radikal bebas ialah dengan antioksidan. Daun keladi tikus diduga memiliki senyawa antioksidan yang dapat menghambat pertumbuhan sel kanker. Untuk mengetahui aktivitas antioksidan daun keladi tikus digunakan metode DPPH dan menghitung nilai $\mathrm{IC}_{50}$. Tujuan dari penelitian ini adalah untuk mengetahui nilai $\mathrm{IC}_{50}$ pada eksrak etanol daun keladi tikus dengan metode DPPH dan mengetahui aktivitas antioksidan ekstrak etanol daun Keladi tikus.

\section{BAHAN DAN METODE}

Bahan. Bahan tanaman yang digunakan dalam penelitian daun Keladi tikus (Typhonium flagelliforme) diperoleh di Desa Sidakarya,

• email korespondensi: agusaick@gmail.com 
Kecamatan Denpasar selatan, provinsi Bali yang telah dideterminasi di LIPI. Bahan kimia yang dipakai yaitu etanol 80\%, 96\%, dan baku DPPH (2,2-difenil-1-pikrilhidrasil).

\section{Metode.}

Ekstraksi simplisia daun keladi tikus. Daun simplisia keladi tikus yang dipetik di daerah Sidakarya, kemudian di keringkan di oven dengan suhu $40^{\circ} \mathrm{C}$. kemudian diperoleh simplisia daun keladi tikus kering, Simplisia daun keladi tikus sebanyak \pm 10 gram dipotong - potong, kemudian diblender sehingga diperoleh serbuk, kemudian ditambah etanol $80 \%$ sebanyak $90 \mathrm{~mL}$ dalam beker gelas, lalu diultrasonik selama $3 \times 3$ menit. Setiap 3 menit dilakukan pengadukan sebelum diultrasonik kembali. Hasilnya disaring, filtrate ditampung, residu yang didapatkan dimasukkan kebeker gelas, ditambah, etanol $80 \%$ sebanyak 90 $\mathrm{mL}$ dan diultrasonik kembali selama 3 × 3 menit, filtrat digabung dengan filtrat pertama. Demikian seterusnya hingga total pelarut etanol $80 \%$ yang digunakan sebanyak $270 \mathrm{~mL}$. Selanjutnya filtrat yang diperoleh diuapkan menggunakan oven dengan suhu $40^{\circ} \mathrm{C}$ hingga didapatkan ekstrak kental.

\section{Pengujian Aktivitas Antioksidan.}

Pembuatan Baku Induk. Dibuat larutan induk ekstrak etanol daun keladi tikus dengan konsentrasi 100 ppm dengan menimbang 2,5 mg ekstrak kental dimasukkan ke dalam labu terukur $25 \mathrm{ml}$, kemudian dilarutkan dengan $25 \mathrm{ml}$ etanol $96 \%$ dikocok hingga homogen.

Pembuatan Sampel Uji. Pembuatan Larutan Ekstrak Etanol Daun Keladi Tikus konsentrasi 10, 20, 30, 40, 50, dan 60 ppm. Dari larutan induk Ekstrak Etanol daun keladi tikus, dipipet sebanyak 0,$5 ; 1 ; 1,5 ; 2 ; 2,5$, dan $3 \mathrm{ml}$ masing- masing dimasukan kedalam labu tentukur $5 \mathrm{ml}$, ditambahkan etanol $96 \%$ sampai tanda batas. Kemudian dikocok sampai homogen.

Pembuatan Larutan Baku Induk DPPH konsentrasi 100 ppm. Ditimbang $5 \mathrm{mg}$ serbuk DPPH dimasukkan kedalam labu terukur $100 \mathrm{ml}$, ditambahkan $50 \mathrm{ml}$ etanol $96 \%$ dikocok hingga homogen.

Pembuatan Larutan Baku Kerja DPPH Konsentrasi 40 ppm. Dari larutan baku induk DPPH 100 ppm dipipet sebanyak $8 \mathrm{ml}$ dimasukkan kedalam labu terukur $25 \mathrm{ml}$ dan ditambah etanol 96\% sampai tanda batas, dikocok hingga homogen.
Penetuan Panjang Gelombang Maksimum larutan Baku DPPH. Larutan baku DPPH 40 ppm dipipet sebanyak $4 \mathrm{ml}$ dimasukkan kedalam kuvet dan diukur dengan spektrofotometer UV-Vis, kemudian dicatat absorbansinya pada panjang gelombang 400-800 $\mathrm{nm}$. Sebagai blangko digunakan $4 \mathrm{~mL}$ etanol 96\%. Dari kurva serapan, ditentukan panjang gelombang maksimum.

\section{Pengukuran Aktivitas Peredaman Radikal} Bebas DPPH dengan Spektrofotometer UVVIS. Larutan sampel uji dengan konsentrasi 10, 20, 30, 40, 50, dan $60 \mathrm{ppm}$. masing - masing dipipet sebanyak $2 \mathrm{~mL}$, kemudian dimasukan pada masing-masing tabung reaksi, selanjutnya larutan baku kerja DPPH 40 ppm dipipet sebanyak $2 \mathrm{ml}$ dimasukkan ke dalam tabung reaksi ditambah etanol $96 \%$ sebanyak $2 \mathrm{~mL}$, kemudian semua larutan dalam tabung reaksi didiamkan selama 30 menit. Lalu diukur dengan spektrofotometer UVVis dan dicatat absorbansinya.

Penentuan Nilai $\mathrm{IC}_{50}$ dan Pembuatan Kurva Kalibrasi. Dari hasil absorbansi yang diperoleh pada masing-masing konsentrasi yang diuji didapatkan nilai presentase peredaman dengan rumus:

$$
\text { \%peredaman }=\frac{\text { absorbansi DPPH }- \text { absorbansi smpel }}{\text { absorbansi DPPH }} \times 100 \%
$$

Dari nilai presentase peredaman pada masingmasing konsentrasi, selanjutnya dibuat kurva regresi, sehingga didapatkan persamaan $\mathrm{y}=\mathrm{bx}+\mathrm{a}$ dan akan diperoleh nilai $\mathrm{IC}_{50}$ dengan perhitungan secara regresi linear dimana konsentrasi ekstrak (ppm) sebagai absis (sumbu $\mathrm{x}$ ) dan nilai presentase peredaman sebagai ordinatnya (sumbu y). Nilai $\mathrm{IC}_{50}$ didapatkan dari perhitungan persentase peredaman sebesar 50. Nilai $\mathrm{IC}_{50}$ (inhibitory concentration) yaitu konsentrasi sampel yang memiliki penghabatan absorbansi DPPH sebesar $50 \%$. Semakin rendah nilai $\mathrm{IC}_{50}$ menunjukan aktivitas antioksidan yang semakin tinggi.

\section{HASIL DAN PEMBAHASAN}

Hasil Penyiapan dan Meserasi Sampel. Hasil penyiapan sampel diperoleh serbuk simplisia daun keladi tikus sebanyak 10 gram. Kemudian sebanyak 10 gram serbuk diekstraksi dengan elmasonik dengan pelarut etanol $80 \%$ didapat filtrat dan dipekatkan didapat ekstrak kental sebanyak $51,27 \mathrm{mg}$. 
Hasil Penentuan Panjang Gelombang Maksimum. Penentuan panjang gelombang maksimum DPPH dengan mengukur serapan larutan DPPH 40 ppm pada panjang gelombang $400-800 \mathrm{~nm}$.

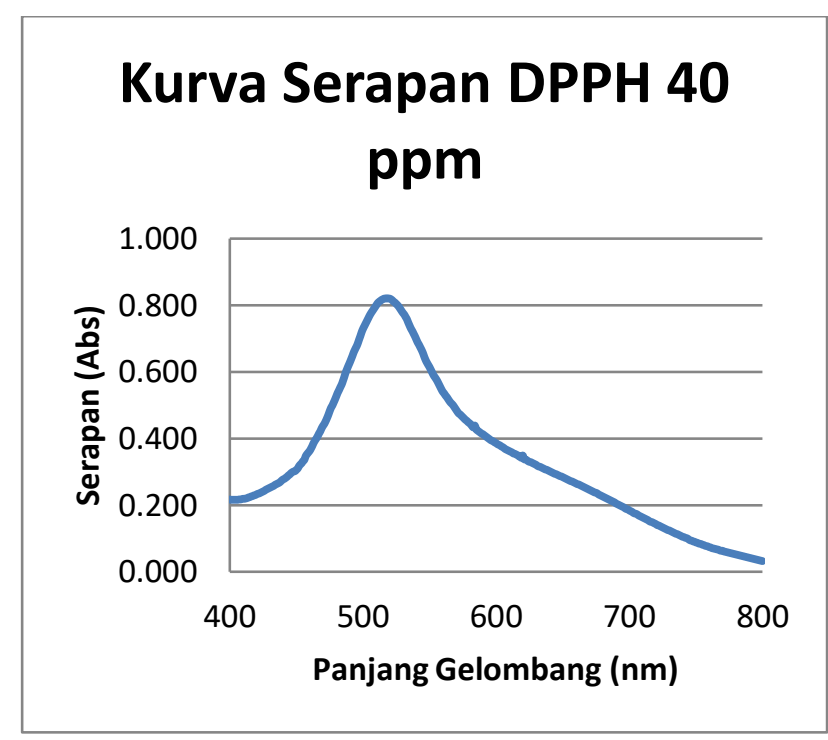

\section{Gambar Panjang Gelombang DPPH}

Dari gambar dapat diketahui bahwa panjang gelombang maksimum DPPH adalah $518 \mathrm{~nm}$.

Pengujian Aktivitas Antioksidan. Pengujian aktivitas antioksidan pada ekstrak daun Keladi Tikus dengan alat Spektrofotometri UV - Vis, dibuat 6 larutan sampel uji dengan konsentrasi akhir berturut - turut 5, 10, 15, 20, 25 dan 30 ppm. Kemudian masing - masing sampel diukur serapannya pada $\lambda \max 518 \mathrm{~nm}$. Pengukuran dilakukan sebanyak 2 kali (duplo). Dari data serapan yang diperoleh, kemudian dilakukan perhitungan peredaman DPPH menggunakan rumus:

$\%$ peredaman $=\frac{\text { absorbansi DPPH }- \text { absorbansi sampel }}{\text { absorbansi } \mathrm{DPPH}} \times 100 \%$

Hasil perhitungan persen peredaman DPPH ekstrak etanol keladi tikus dapat dilihat pada tabel
Tabel Persen peredaman DPPH ekstrak etanol daun Keladi Tikus

\begin{tabular}{|c|c|c|c|}
\hline \multirow{2}{*}{$\begin{array}{c}\text { Konsentrasi } \\
\text { (ppm) }\end{array}$} & \multicolumn{3}{|c|}{ \% Peredaman DPPH } \\
\cline { 2 - 4 } & Pengujian 1 & Pengujian 2 & Rata - rata \\
\hline 5 & 6.32 & 19.79 & 13.05 \\
\hline 10 & 7.95 & 20.40 & 14.17 \\
\hline 15 & 11.63 & 24.48 & 18.05 \\
\hline 20 & 14.89 & 25.10 & 19.99 \\
\hline 25 & 19.79 & 27.55 & 23.67 \\
\hline 30 & 21.42 & 29.38 & 25.40 \\
\hline
\end{tabular}

\section{Perhitungan Nilai $\mathbf{I C}_{\mathbf{5 0}}$}

Dari persentase peredaman dibuat kurva regresi linier. Kurva regresi linier dapat dilihat pada gambar

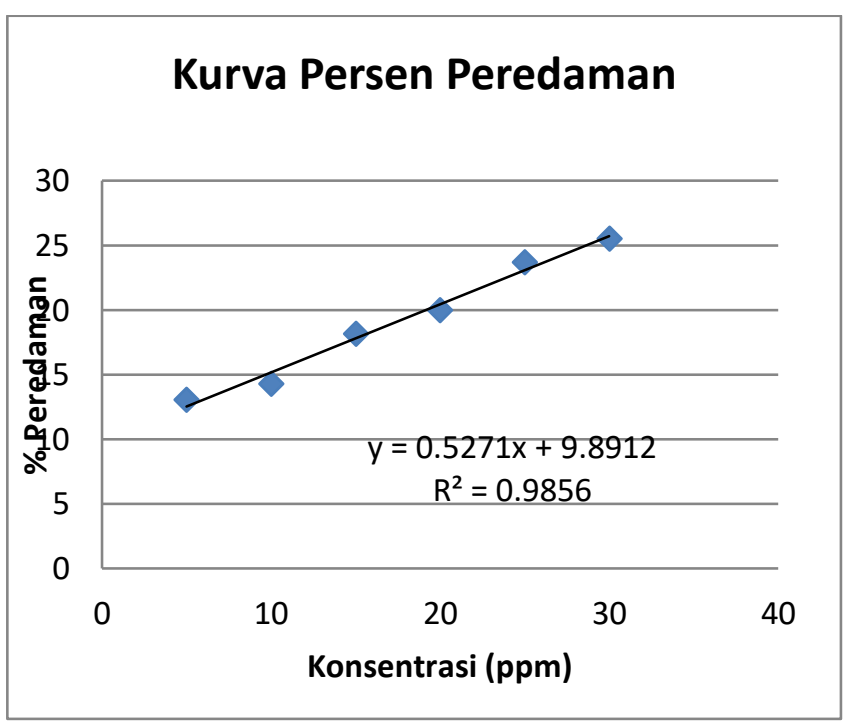

\section{Gambar Kurva regresi linier}

Dari kurva hubungan antara konsentrasi larutan uji dengan persen peredaman diatas didapat persamaan regresi $\mathrm{y}=0.527 \mathrm{x}+9.891$. Dari persamaan tersebut dilakukan perhitungan nilai $\mathrm{IC}_{50}$ dengan mengganti nilai $\mathrm{y}=50$. Hasil yang diperoleh menunjukkan bahwa nilai $\mathrm{IC}_{50}$ ekstrak etanol daun keladi tikus adalah 76.10 ppm. 


\section{SIMPULAN}

Dari serangkaiam penelitian yang telah dilakukan maka dapat disimpulkan bahwa ekstrak etanol daun Keladi tikus (Typhonium flagelliforme) memiliki nilai $\mathrm{IC}_{50}$ sebesar $76.10 \mathrm{ppm}$ dan memiliki aktivitas antioksidan kuat.

\section{DAFTAR PUSTAKA}

Affandi Yusuf. 2006. Daya hambat ekstrak air dan etanol keladi tikus (Typhonium flagelliforme) terhadap enzim tirosin kinase secara in vitro.Bogor, Departemen kimia fakultas matematika dan ilmu pengetahuan alam institut pertanian bogor

Blaszczyk, Alina, Aleksandra Augustyniak, and Janusz Skolimowski. 2013.Ethoxyquin: An Antioxsidant Used in Animal Feed. International journal of food science. Volume 2013.

Departemen Kesehatan RI. Parameter Standar Umum Ekstrak Tumbuhan Obat. Direktorat Jendral Pengawasan Obat dan Makanan. Jakarta : Depkes RI. 2000.hal. $1-12$.

Dedy Irawan. 2006 Penentuan Aktivitas Antioksidan Ekstrak Mahkota Dewa, Temu Putih, Sambiloto, Dan Keladi Tikus Secara In Vitro. Bogor. Departemen kimia fakultas matematika dan ilmu pengetahuan alam institut pertanian Bogor.

Droge, W. 2002. Free radicals in the physiological control of cellfunction. Physiol, 82, 4795.

Ismail. 2013. Studi Potensi Ekstrak Etanol 80\% Garuga Floribunda, Ochrusia Akkeringae, Tabernaemontana Pandacaqui Melalui Uji Aktifitas Antiradikal Bebas Secara In Vitro. Surabaya. Fakultas Farmasi Universitas Airlangga Departemen Farmakognosi dan Fitokimia Surabaya.

Katrin Ermin 1, Fahrul Nizar Novagusda2, Susanto1 dan Hendig Winarno1. 2012. Karakteristik dan Khasiat Daun Keladi Tikus (Typhonium divaricatum (L.) Decne) Iradiasi. Fakultas Farmasi, Universitas Pancasila.
Khopkar. 1990. Konsep Dasar Kimia Analitik. Jakarta : UI-Press.

Maria Inggrid, Dra. H, Msc. Dan Herry Santoso, ST., M.T.M., PhD. 2014. Ekstraksi Antioksidan dan Senyawa Aktif dari Buah Kiwi (Actinidia deliciosa). Lembaga Penelitian dan Pengabdian kepada Masyarakat Universitas Katolik Parahyangan.

Miryanti A, Sapei L, Budiono K, Indra S, 2011, Ekstraksi Antioksidan dari Kulit Buah Manggis (Garcinia mangostana L.), Jurnal Universitas Parahyangan, lembaga penelitian dan pengabdian.

Prakash, A., Rigelhof, F., Miller, E., 2001, Antioksidan Activity, Medalliaon Laboratories Analitycal Progress, vol $19: 1$ -6 .

Putri Raden Nabilla Ayesha. 2012. Uji aktivitas antioksidan ekstrak daun sirsak (annona muricata L.) dengan metode DPPH (1,1Diphenyl-2-Picrylhydrazil). Jakarta. Program studi pendidikan dokter fakultas kedokteran dan ilmu kesehatan universitas islam negeri hidayatullah Jakarta.

Sampoerno dan D. Fardiaz. 2001. Kebijakan dan pengembangan fungsional dan suplemen di Indonesia. Dalam I. Nuraida dan R.D. Hariyadi (Ed). Pangan Tradisional Basis Bagi Industri Pangan Fungsional Suplemen. Pusat Kajian Makanan Tradisional, Institut Pertanian Bogor. Hlm $1-15$.

Sarastani, D., Soekarto, S T., Muchtadi, T R., Fardias, D., Supriyanto, A. 2002. Aktivitas Antioksidan Ekstrak dan Fraksi Biji Atung. Teknologi dan industry pangan, 13 (2), 149-156.

Setiaji Guntur. 2014. Karakterisasi dan uji aktivitas antioksidan minyak hasil ekstrasi biji honje (Etlingera elatior). Program studi kimia fakultas sains dan teknologi universitas islam negri syarif hidayatullah Jakarta.

Syahid. 2008 Keragaman Morfologi, Pertumbuhan, Produksi, Mutu dan Fitokimia Keladi Tikus (Typonium 
flagelliforme Lodd) Blume Asal Variasi Somaklonal, Balai Penelitian Tanaman Obat dan Aromatik, Bogor.

Winarsi, H. 2007. Antioksidan Alami dan Radikal Bebas. Yogyakarta: Kanisius

Wulandari M, Idiwati N, Gusrizal, 2013, Aktivitas Antioksidan Ekstrak n- Heksana,
Etil Asetat dan Metanol Kulit Buah Jeruk Sambal (Citrus microcarpa Bunge), Vol 2(2), 90-94

Zakaria FR. 2001 Pangan dan pencegahan kanker. Jurnal teknol dan Industri Pangan 12:171177 